\title{
Electoral Politics in the Context of Separatism and Political Divergence: An Analysis of 2009 Parliamentary elections in Jammu \& Kashmir
}

Rekha Chowdhary

\section{(2) OpenEdition}

\section{Journals}

Electronic version

URL: http://journals.openedition.org/samaj/2785

DOI: $10.4000 /$ samaj.2785

ISSN: 1960-6060

Publisher

Association pour la recherche sur l'Asie du Sud (ARAS)

\section{Electronic reference}

Rekha Chowdhary, «Electoral Politics in the Context of Separatism and Political Divergence: An Analysis of 2009 Parliamentary elections in Jammu \& Kashmir », South Asia Multidisciplinary Academic Journal [Online], 3 | 2009, Online since 23 December 2009, connection on 19 April 2019. URL : http:// journals.openedition.org/samaj/2785 ; DOI : 10.4000/samaj.2785

This text was automatically generated on 19 April 2019

\section{(c) $(1)$}

This work is licensed under a Creative Commons Attribution-NonCommercial-NoDerivatives 4.0 International License. 


\title{
Electoral Politics in the Context of Separatism and Political Divergence: An Analysis of 2009 Parliamentary elections in Jammu \& Kashmir
}

\author{
Rekha Chowdhary
}

1 As in any other state of India, the 2009 Parliamentary election in the State of Jammu and Kashmir can be seen as an important moment reflecting the nature and direction of politics as it is evolving at the local level. One can gauge the changing nature of power politics; the context of popular participation; the nature of competition and the intensity and depth of democracy in the State. However, the context of the conflict situation which has engulfed this state for the past two decades provides additional meaning to the electoral exercise here. This paper will therefore seek to locate the Parliamentary elections in the context of separatism. Specifically, it will focus on the implications of parallel existence of the separatist and the mainstream politics on power politics of the State. Separatism, it may be mentioned here, emerged as the dominant political response in Kashmir during the post-1989 period. Manifested simultaneously through armed militancy as well as spontaneous popular upsurge, this political response has continued to have a hold over the politics of the Valley throughout the last two decades. ${ }^{1}$ Despite the restoration of mainstream politics after its complete erosion during the initial stages of separatism, the separatist politics continues to define the political responses of Kashmir. The two kinds of politics seem to be operating side by side, overlapping at a number of points and impacting each other in an interesting manner. It is in this context of overlap between the separatist and mainstream politics that the 2009 Parliamentary election will be analysed.

2 The paper will also highlight the context of diversity and political divergence within the state and its implications on electoral politics. Focusing on the political divergence at the regional level, it will analyse the process of political mobilisation around the regional identity politics. 
3 The immediate context of the elections is framed by two significant political events that preceed these elections-first, the Amarnath agitation which engulfed almost the whole state during the summer of 2008 and Assembly elections that were concluded in December 2008.

\section{The context of electoral politics in Kashmir. Implications of conflict situation and separatist politics}

4 The state of Jammu and Kashmir has been affected by the conflict situation ever since 1947. The ruler of this erstwhile Princely state, after remaining indecisive for quite some time, signed the instrument of Accession with India under troubled conditions created by the tribal invaders supported by Pakistan army, on $26^{\text {th }}$ October 1947. The issue assumed international character with India taking the case to the UN. With Pakistan holding on a part of J\&K and contesting the validity of Accession of the other part with India, this State continued to remain a bone of contention between the two countries.

5 However, besides external dimension of the conflict which has afflicted this state ever since 1947, there is also an internal dimension which is defined by Kashmir's relationship with India. This relation has witnessed a protracted tension, especially since 1953. In 1953, Sheikh Abdullah, the popular Kashmiri leader was removed from power and detained for a long time. Before his detention, Sheikh had been instrumental in negotiating a special constitutional status for the state. However, with his dismissal not only this status was gradually eroded, but Kashmiris were also denied democratic channels of political expression. Excessive central intrusion in the politics of the state distorted even the most developed indigenous political institutions like the National Conference and distanced governance from the popular responses (Bose 2003: 66-7) All this resulted in an accumulated political discontent which was manifested throughout the post-1953 period.

6 Though Sheikh was brought back to power in 1975, political discontent continued to manifest itself. One of the major reasons for this discontent was the lack of any initiative in restoring the constitutional autonomy of the state, the major pre-condition of Sheikh for resuming power. However, due to the towering personality of the Sheikh, particularly his capacity to assert autonomy of his government vis-à-vis the intrusive politics of the Centre, the discontent was quite subdued. But the incapacity of his successor and son, Dr. Farooq Abdullah, to keep the Centre away from meddling into the politics of the state, resulted in intensifying the already existing feeling of discontent. The tension continued to grow after the dismissal, engineered by the Congress-the ruling party in the Centre-, of Farooq Abbdullah's government, which had obtained a massive popular mandate during the 1983 Assembly elections, (Abdullah 1985: 9). In addition, the pressure built upon Farooq Abdullah and the National Conference to enter into an electoral alliance with the Congress party increased the dissatisfaction, since the Congress party was popularly held responsible for distorting local politics since early fifties.

7 However, the real political outrage in the Valley was triggered by the 1987 Assembly election, generally perceived to be highly rigged, which led to the massive victory of NCCongress combine and the defeat of most of the Muslim United Front (MUF) candidates. The MUF was formed in 1986 to give vent to the growing popular resentment against the 
alliance were seen to be manipulated. Despite polling $38.2 \%$ votes (compared to $45.2 \%$ votes of the NC-Congress combine), the opposition comprised of MUF and People's Conference ${ }^{2}$ could register victory barely in four constituencies. The fact that the margin of victory of some of the candidates belonging to the ruling combine was very low, and the number of invalid votes in these constituencies was quite high, generated a feeling of scepticism regarding the validity of the results ${ }^{3}$ (Chowdhary \& Rao 2003: 189-219).

It was in the wake of disillusionment with the internal politics in general that the present phase of conflict was started in the Valley. What marked the beginning of this phase was the decision of some of the Kashmiri youth who had participated in the elections as contestants, election agents, campaigners and sympathisers of candidates to cross over to Pakistan administered Kashmir to take training in armed militancy. Moreover, apart from armed militancy, a spontaneous popular upsurge grew against the Indian State that eroded the mainstream politics in the Valley of Kashmir. The separatist politics manifested both through the armed militancy as well as spontaneous political response took a more organised form with the establishment of the All Party Hurriyat Conference (APHC) in 1993. The establishment of APHC as an umbrella organisation was necessitated by the proliferation of militant groups which were at times operating at cross purposes. The ideological differences between these organisations and their internal strife, especially the war declared by Hizbul Mujahideen on the JKLF, generated a need for a loose-knit organisation that could give a sense of unity and common direction to those participating in the movement (Schofield 2000: 143-88).

9 So much was the sway of the separatist politics in the Kashmir Valley, that it completely eroded the mainstream politics right from 1989. While Jammu and Ladakh regions remained more or less normal, there was no scope for the mainstream power politics in the Valley. ${ }^{4}$ As the legitimacy of the mainstream politics was openly questioned by the militants on the one hand, and the defiant masses on the streets of Kashmir on the other, the state was placed under the President's rule for a prolonged period of time. In 1996, the electoral process was restored but the government that was formed after the Assembly election could not gain credence in the Valley of Kashmir. Since the elections were organised with the help of the security forces and the counter-insurgents, the government formed after the elections was not seen to be representing the popular will. Though NC had given the slogan of 'autonomy' to regain its hold in the local politics, there were not many takers of this slogan (Chowdhary 2000: 2600-1).

Despite the restoration of political process, separatist sentiment continued to hold sway. Though Kashmiris, by this time, had started reacting against the 'culture of violence' and very subtly rejecting and de-legitimising militancy, their sympathies with separatist politics continued to be expressed through various demonstrations organised by the Hurriyat Conference. Mainstream politics, therefore, continued to remain challenged.

11 A number of factors changed the popular response towards electoral and mainstream politics. Firstly, the urge for normalcy after the prolonged period of militant violence led to some kind of change of attitude towards the process of governance. By the time the 2002 Assembly election was concluded, the political processes related to governance had already found some legitimate space in Kashmir's politics. Without any contradiction towards their separatist sentiments, people started involving themselves in the 'politics related to governance'. This process was further boosted by a change in the nature of political mobilisation. With the emergence of People's Democratic Party (PDP) as another Kashmir-based party, not only the electoral competition became quite intense, but the 
electoral discourse also became more grounded in the local realities. PDP referred to the Human Rights violations taking place in Kashmir and the need for providing 'healing touch' to people, and also raised the issue of conflict and its resolution through the process of dialogue both with both Pakistan and militants. Also significant were the initiatives being taken by the Vajpayee-led Government: declaring that India had made mistakes in Kashmir, Vajpayee made a commitment to hold a 'free and fair election'. This commitment was an indirect acknowledgement of the intrusive role that the Centre had been playing in the power politics of the State since 1950s.

The impact of all these factors was significantly visible through the voters' response. Although the overall turnout during the 2002 Assembly elections was much lower than the 1996 Assembly elections, the participation was more voluntary rather than coerced by the presence of security forces in any manner, which made the 30\% turnout in Kashmir Valley quite significant. ${ }^{5}$

13 The 2002 Assembly elections, generally acknowledged to be fair, helped build some kind of confidence in the electoral institutions and processes. Till now, the formation of government and its sustenance in power was more dependent on the support of the Centre rather than the mandate of people. The electoral politics therefore was quite distanced from the popular responses. ${ }^{6}$ Breaking the hegemony of the single dominant party also brought an alternative to the PDP-Congress coalition power. The possibility that a government could be changed through the participation of people in the electoral process, rather than through the manipulative politics of the Centre, strengthened the stake of the people in this process.

Moreover, the response of people towards the electoral process was further transformed through the intensity of competition after the creation of the People's Democratic Party. The emergence of another Kashmir-based political party invigorated the mainstream political space.

Before the emergence of Peoples Democratic Party (PDP), National Conference (NC) had hegemonised the politics of Kashmir region (Chowdhary \& Rao 2004: 1521-7). It based its on playing a role in organising the resistance movement against the feudal Dogra rule before 1947 and the radical land reforms that it had initiated after it came into power in 1947. Its emphasis on economic and political reconstruction of the state, in pursuance of the New Kashmir Manifesto, the ideological blueprint of the party-particularly the redistribution of the land to the landless, debt relief to the peasants, free education till the Post Graduate stage-endeared this party to the Kashmiri masses and they formed the base of this party. The support was strengthened by Sheikh Abdullah's charisma until his removal from power in $1953 .^{7}$

With the ouster of the Sheikh Abdullah from power and subsequent formation of Plebiscite Front, the support base of NC shifted to this organisation in the post-1953 period. However, NC continued to officially operate as the ruling party of the state under the leadership of Bakshi Ghulam Mohammed. But the ruling NC legitimacy remained contested throughout and it survived more on the basis of the support from the Congress party than on the basis of local support. So overwhelming was the influence of the Congress that the NC ultimately merged with it in mid-sixties. After 1975 when Sheikh Abdullah came back to power politics, the Plebiscite Front was dissolved and the NC was revived. From 1975 to 1996, the NC was again the most influential party of Jammu and Kashmir, particularly in the Valley. 

gradually declined. In the background of the Kashmir's politics between 1953 and 1975 when people were mobilised around the theme of contestation of the existing relationship of the state with India, the return of Sheikh Abdullah to power without much change in the status quo, there was a simmering discontent in the Valley. However, due to the towering personality of Sheikh Abdullah, much of this discontent did not take a concrete shape during his life time. But after his death, the party now led by his son Farooq Abdullah started losing space. Even when Congress as the ruling party in the Centre had manoeuvred the ouster of his government in 1984, he had entered into an alliance with this party in 1986 and contested the 1987 election leading this alliance. mass support at the ground level, it distanced itself from popular concerns. That the party, despite obtaining massive mandate was disconnected from popular responses became clear in 1989 when the Valley came in the grip of militancy and witnessed a massive upsurge (Schofield 2003: 143-88). ${ }^{8}$ In the political crisis that ensued, not only NC was forced to withdraw from the political scene but had to face the maximum brunt of violence. Devoid of legitimacy, NC leadership went into hibernation. And even after coming back on the political scene by contesting the 1996 Assembly election and forming the government, it could not regain its previous legitimacy.

With the emergence of PDP in late nineties, the context of the power politics changed drastically. As another Kashmir-based party, it not only challenged the dominance of the $\mathrm{NC}$ but changed the very logic of power politics. Adopting a political discourse that reflected the popular concerns of people in a situation of conflict, PDP sought to reduce the gap between popular aspirations and the power politics. It borrowed issues from the separatist camp and brought them to the centre of mainstream political space. Thus the party suggested 'dialogue' with the militants and separatists as a way towards solving the conflict; easing out pressure upon people from the excessive presence of the security forces; and reducing drastically the number of cases of Human Rights violations. It was this 'people-oriented' strategy of PDP that helped bring an end the hegemony of NC. During the 2002 Assembly elections, the PDP managed to capture as many as 16 seats from Kashmir Valley. ${ }^{9}$

The mainstream political space was able to expand substantially during the period between 2002 and 2008. From a situation in pre-2002 period when political parties and leaders could not freely move in public space and could not organise public meetings, 2007 saw frequent rallies being organised by almost all the political parties in various parts of the Valley-in the anticipation of the coming election, almost one year in advance (Chowdhary 2008: 22).

21 Expansion of the electoral space, however, has not taken place at the cost of the separatist sentiment and politics. In fact, the separatist sentiment remains intact in Kashmir. The legitimisation of the mainstream politics has been possible only because there is no contradiction between the separatist and mainstream politics and people are not forced to make a choice between the two. The two are seen as reflecting two different spheres of politics: one dealing with issues relating to governance; and the other dealing with conflict situation and its resolution. Right since the 2002 elections, the political parties have sought to restrict the scope of electoral politics to the issues related to 'governance' only. Recognising the larger political realities of the state, these parties acknowledge the widely prevalent separatist sentiment and the need of addressing it. In 
no way do they claim that the extension of electoral space amounts to shrinking the separatist space.

The parallel existence of the two kinds of politics reflects a complexity that exists at the ground level, generated both by the change in the dynamics of the separatist politics, and the nature of popular responses. With the decline in armed militancy, the assertion of the separatist sentiments is taking place through the mass politics. The more the mainstream politics is expanding, the more it becomes rooted in local responses, while generating a need to reaffirm the popular separatist sentiments. In a situation where conflict resolution has not taken a concrete shape, a danger is always felt that participation in mainstream politics may be a sign of political normalcy which might put the whole question of conflict resolution to the back burner. Thus has emerged the very peculiar situation in Kashmir, where mainstream political processes and assertion of separatist sentiments alternate. It is interesting to note how abruptly the situation changes in the Valley. While there was a tremendous electoral upsurge throughout the year of 2007 and early 2008, it was suddenly halted by an equally strong assertion of separatist politics during the Amarnath agitation. The affirmation of the mainstream politics immediately followed when people participated in large number during the 2008 Assembly elections.

\section{The Amarnath agitation}

Amarnath land row engulfed the whole state throughout the summer of 2008. To begin with, there was a massive agitation in Kashmir, which was followed by a prolonged agitation in Jammu. This was once again followed by a renewed mass upsurge in Kashmir. The entire issue initially revolved around a government order diverting forest land to Shri Amarnath Shrine Board (SASB), and subsequently around the revocation of the same order. ${ }^{10}$ The order gave the SASB the right to erect pre-fabricated temporary structures for housing pilgrims during the period of the Amarnath yatra. However, more than the order, it was the assertion of the Chief Executive Officer (CEO) of the SASB-representing the ex-officio chairman, the Governor, General S.K. Sinha-, that land had been given permanently to the Board to build permanent structures that generated a massive response in Kashmir. ${ }^{11}$

The separatists used the issue of diversion of land to SASB to create suspicion of a grand design behind the order aimed at altering the Muslim-majority character of the state. The fear of 'demographic change', therefore, became the basis of mass mobilization in Kashmir. To quell the agitation which had assumed dangerous proportions in Kashmir, the order was revoked but this only generated another kind of polemics in Jammu. The Bharatiya Janata Party and like-minded organizations termed the revocation as an assault on 'Hindu sentiments' and demanded restoration of the original order. The revocation of the order was portrayed as anti-Jammu decision taken under the pressure of separatists to appease the 'Muslims of Kashmir' without taking into consideration the sentiments of the 'Hindus of Jammu'.

In both the regions, the agitation brought in focus the radical elements who sought to mobilise people around emotive issues. In Kashmir, people were mobilised by the Geelaniled Hurriyat Conference (as well as by the PDP) around the fear of demographic change (the fear that by systematic efforts the Muslim-majority character of the State will be changed) and in Jammu, the mobilisation took place around the religious sentiments of Hindus (supposedly hurt by the revocation of the Land Order). 
The agitation had far reaching implications for the politics of the State. In the Valley of Kashmir, there was aggressive affirmation of separatist sentiments reminding one of the massive popular demonstrations of early 1990 . However, unlike the separatism of the last few years which was marked by the centrality of moderate leadership, it was now directed by hardliners.

The public display of the separatist sentiments during this time gave an indication that beyond the electoral vibrancy, the deep-rooted sense of alienation continued to prevail. Throughout the period of agitation one could feel that the mainstream politics had once more regressed to the background and the separatist politics had become ascendant.

A significant implication of the Amarnath agitation was the fractured relationship between Jammu and Kashmir. Though politically divergent, the two major regions had never been placed in such an antagonistic relationship. ${ }^{12}$ The political discord had reached beyond the usual issues of regional disparities and had started affecting the economic and trade relationship between the two regions. The most dangerous implication of the agitation was the communally divisive mobilisation and the resultant communal tension in the state.

Along with the religious factor, it was the regional identity politics that provided stimulus to the Amarnath agitation. In Jammu, a feeling of political discontent has been persisting since early fifties. The feeling emanates from the context of power politics of the State which is perceived to be 'Kashmir-centric' having negligible or token presence of Jammu's political elite (Puri 1966: 77-81). It also has much to do with the specificity of the conflict situation of Kashmir and the response of the Central government. There is a feeling that in all political negotiations undertaken to address the Kashmir problem, Jammu is taken for granted and that the political arrangements are imposed on this region. This feeling is accentuated by the context of political divergence and the ideological divide between the two regions. The logic of Kashmir's dominant politics governed by the contestation of the State's relationship with India and manifested through the discourse of 'Autonomy'/'Azadi' does not extend itself to the Jammu region. The politics of this region on the contrary, is governed by the regional asymmetry in the power politics and resource distribution.

The dominant political discourse of Jammu revolves around the issues related to regional 'deprivation and neglect'. 'Kashmir' in this discourse forms the 'centre of power' within the state and is perceived to be dominating both the power structure of the state and the economic and material resources. It is on this basis that popular perceptions have been articulated around the notion of regional imbalances and a number of agitations have been organised in Jammu. The context of regional divergence and regional imbalances has come to overwhelm the political logic of Jammu, not only in the Hindu-dominated areas where organisations of Hindu-Right have been mobilising people around the demand for abolition of Article 370 guaranteeing the special status of the State, but also in the Muslim-dominated districts which are relatively more backward. Leaders here blame the Kashmir-centric power politics for the perpetual neglect of these districts. Ever since the early fifties, there has been a perception throughout Jammu region that the public policy and political decisions favour Kashmir while ignoring Jammu. The political response of the region is therefore organised around the issue of regional imbalances. The range of this response however varies from the demand for regional autonomy (emanating from the centrist politics), to the demand for a separate state of Jammu (emanating from the Hindu Rightist politics). There is also a third demand, coming from 
backward areas of Jammu region, for some kind of sub-regional arrangement (the Hill Development Councils for instance).

31 Regional divergence has been manifested in the politics of the state in a variety of manners. However, despite this divergence the two regions of the state never followed a confrontationist path. It was during the period of militancy that the political divergence was reflected in a sharp manner. However, even this did not result in collision between the two regions. On the contrary, there evolved a feeling that despite the specificity of conflict in the Kashmir region, there was a need to evolve a consensus between the two regions. The conflict resolution process, it was understood (both by the political elite in Kashmir as well as in Jammu) needed to be inclusive so as to represent the divergent political voices within the State.

Amarnath agitation became the first occasion in the history of politics of the state when the two major regions of the state were placed in an antagonistic situation. Both in Jammu as well as in Kashmir, the masses were mobilised in a manner that enhanced regional chauvinism. Worse still, the mobilisation ultimately took a communal route and resulted not only in the tension between the two major communities of the state but also in carving of new political constituencies based on religion.

In the absence of a regional party, the politics of regional discontent is often appropriated by the Hindu Rightist parties and organisations which combine regional issues with religious sentiments. Since the onset of militancy, the parties of Hindu Right have sought to sharpen the regional identity politics. ${ }^{13}$ Amarnath agitation was one such occasion when the Hindu Rightist organisations could mobilise masses in Hindu dominated areas of Jammu by arousing regional sentiment combined with religious one.

Regional chauvinism not only dominated the Jammu region, but Kashmir as well. After the onset of the coalition era which gave a visibility to Jammu in the power politics, a politics has been generated in Kashmir around the issue of its discrimination vis-à-vis Jammu. In radicalising the regional politics of Kashmir, PDP has had a clear role to play. In its competition with $\mathrm{NC}$, this party has often sought to give an aggressive edge to Kashmiri regional politics and also add religious dimensions to it. One could clearly see the role of PDP in raising the regional sentiments in Kashmir during the Amarnath agitation. Though responsible for taking the decision on transfer of land to the SASB, this party joined the side of agitators to demand its revocation, terming the Land Order as an assault to Kashmiri identity and endangering the Muslim-dominated character of the State.

\section{The 2008 Assembly elections}

The 2008 elections took place immediately after the Amarnath agitation. The unprecedented regional and communal polarisation that afflicted the state during this agitation, therefore, was bound to have repercussions on this election.

In the Valley, separatist politics was the highlight of the agitation. The separatist leadership had developed a renewed confidence that people who had participated in massive demonstrations against the Indian state during the agitation would not come forward to participate in elections, and the electoral exercise would once again be reduced to a farce. However, the boycott call was defied and there was massive participation of people in the Assembly election. Against 29.64\% voter turnout in the 2002 
Assembly election, the 2008 election recorded 51.64\%. In almost all the districts and all the constituencies of the Valley, the percentage of the voter-turnout was much higher than the last Assembly elections. Throughout the Valley one could see the images of long queues outside the polling booth showing the eagerness to cast votes. The message was very clear: despite the centrality of the separatist politics, the mainstream politics has been extended and legitimised. The proximity of the people with the power politics, the location of power politics in local responses of people and their growing stake in the local politics-all had led to the deepening of democracy in this state, particularly in the Valley. ${ }^{14}$ This is why the usual sense of scepticism with regard to the democratic institutions was replaced by a greater involvement in the process of government making.

Table 1. Comparative voter turnout in Kashmir - 2002 and 2008 Assembly elections*

\begin{tabular}{|c|c|c|}
\hline & \multicolumn{2}{|c|}{$\begin{array}{l}\text { Votes polled (in \% } \\
\text { ) }\end{array}$} \\
\hline & 2002 & 2008 \\
\hline $\mathrm{J} \& \mathrm{~K}$ & 43.70 & 60.92 \\
\hline Kashmir & 29.64 & 51.64 \\
\hline Jammu & 55.82 & 70.90 \\
\hline Ladakh & 75.91 & 68.65 \\
\hline
\end{tabular}

* Source: Election Commission of India. All the tables contain data from the Election Commission of India.

Although the voter turnout was not affected by the Amarnath agitation, same is not the case with the electoral outcome. In an intensely contested election which gave a fragmented verdict, PDP and BJP emerged as the gainers. While PDP was able to increase its share of seats in Kashmir region from 16 in 2002 to 19 and its vote percentage arose from $24.48 \%$ to $27.42 \%$, it could also gain entry in Jammu and register its victory in 2 seats with a voter turnout of $6.88 \%$ in its favour. BJP, however emerged as the biggest gainer since it could increase its share of seats from one to eleven. Its vote share in Jammu region increased from $17.80 \%$ to $22.94 \%$.

NC was able to retain 28 seats that it had in 2002, but it suffered some losses in Jammu region where it could win only 6 seats as compared to 9 seats in 2002. Congress also could not fare so well. As against 20 seats in 2002, this time it could win only 17 seats. As against $21.38 \%$ votes in 2002 , only $18.17 \%$ votes were cast in its favour in 2008. It suffered loss both in Jammu (from $26.40 \%$ to $23.98 \%$ ) as well as in Kashmir (from $14.41 \%$ to $10 \%$ ).

Table 2. Comparative percentage of votes polled by different parties - 2002 and 2008 Assembly elections

\begin{tabular}{|l|l|l|l|}
\hline & \multicolumn{2}{|l|}{ Votes Polled (in \%) } \\
\hline & J\&K & $\begin{array}{l}\text { Kashmir } \\
\text { Region }\end{array}$ & $\begin{array}{l}\text { Jammu } \\
\text { Region }\end{array}$ \\
\hline
\end{tabular}




\begin{tabular}{|l|l|l|l|l|l|l|}
\hline & $\mathbf{2 0 0 2}$ & $\mathbf{2 0 0 8}$ & $\mathbf{2 0 0 2}$ & $\mathbf{2 0 0 8}$ & $\mathbf{2 0 0 2}$ & $\mathbf{2 0 0 8}$ \\
\hline NC & 28.23 & 23.59 & 35.62 & 27.50 & 23.95 & 20.16 \\
\hline INC & 21.38 & 18.17 & 14.41 & 10.48 & 26.40 & 23.98 \\
\hline PDP & 09.04 & 15.68 & 24.51 & 27,41 & 01.76 & 06.88 \\
\hline BJP & 12.15 & 12.73 & 01.60 & 00.96 & 17.80 & 22.94 \\
\hline JKNPP & 04.68 & 3.39 & 00.03 & 0.78 & 07.02 & 05.68 \\
\hline
\end{tabular}

Table 3. Comparative share of seats attained by political parties -2002 and 2008 Assembly elections

\begin{tabular}{|l|l|l|l|l|l|l|}
\hline \multicolumn{5}{|l|}{ Number of Seats } \\
\hline & \multicolumn{5}{|l|}{$\begin{array}{l}\text { Kashmir } \\
\text { Jegion }\end{array}$} & \multicolumn{2}{l|}{$\begin{array}{l}\text { Jammu } \\
\text { Region }\end{array}$} \\
\hline & 2002 & 2008 & 2002 & 2008 & 2002 & 2008 \\
\hline NC & 28 & 28 & 18 & 20 & 09 & 06 \\
\hline INC & 20 & 17 & 05 & 03 & 15 & 13 \\
\hline PDP & 16 & 21 & 16 & 19 & 00 & 02 \\
\hline BJP & 01 & 11 & 00 & 00 & 01 & 11 \\
\hline JKNPP & 04 & 03 & 00 & 00 & 04 & 03 \\
\hline
\end{tabular}

The results of Assembly elections clearly reflect the divide created during the agitation. The increase in BJP's and PDP's share of votes and seats follow the successful aggressive mobilisation of the regional and religious identities by these two parties. Rather than the centrist forces represented by Congress and National Conference, it was the triumph for those parties which had stretched the politics of the state to the extremely polarised responses.

Before the Amarnath agitation, PDP was not in a very comfortable position in Kashmir. After remaining in power for more than five years, it was facing the anti-incumbency factor. In the context of its radical pro-Kashmir politics, its association with Congress was becoming a liability. In all likelihood therefore, $\mathrm{NC}$ was poised to win a substantial number of seats in the Valley, had the agitation not taken place. However, the Amarnath agitation changed the situation for the PDP which severed its link with the Congress and joined the side of agitators. Since the agitation honed the Kashmiri regional and separatist sentiments, PDP's gain was ensured. In the regionally polarised politics where Jammu's rightwing forces were provoking anti-Kashmir sentiments, PDP was projecting itself as the redeemer of the Kashmiri sentiment. Its leader Mehbooba Mufti was 
vociferously campaigning against the 'economic blockade' of Kashmir by Jammu's agitators. In this context of regional and communal polarisation, the PDP's increase in popularity was clearly reflected during the Assembly election.

The electoral polarisation on the communal basis was more clearly established in the Jammu region. ${ }^{15}$ Here BJP could register its victory in the record number of 11 seats. The highest number of seats that this party had ever attained was 8 during the 1996 Assembly election, as an immediate post-militancy reaction from the region. In the context of violence, BJP could succeed in extending its constituency. However, as the violence level came down, the influence of BJP also weakened. During the 2002 Assembly election, this party only managed to win one seat.

The constituency of BJP's politics was in any case shrinking due to the changed nature of power politics of the State. The extreme politics of regional discontent on which the popularity of this party depends, was getting blunted in the context of coalitional power sharing. For the first time in the political history of the state, Jammu had a fair share of power in the state. The Congress having its base in Jammu and PDP in Kashmir created a regional balance. ${ }^{16}$

43 It is important to note that since 2002, there was no major protest organised in Jammu region around any regional issue. However, the Amarnath agitation provided space and opportunity for BJP and other like-minded organisations to mobilise the Hindu constituency. The massive mandate in favour of BJP in Jammu's Hindu-dominated districts indicated that region was now getting communally polarised.

The fact that the PDP could register its victory in two Muslim dominated constituencies of the Jammu region provided additional reason to believe the growing impact of communal polarisation. Being a Kashmir-centric party which has been seeking to legitimise its politics by emphasising its 'pro-Kashmir' orientation with a pro-Muslim bias, PDP's entry into Jammu's Muslim dominated areas and its success in two predominantly Muslim constituencies was an indication of the communal polarisation that was taking deeper roots in the State. In a way this reflected a very dangerous signal of an extension of Kashmiri constituency to Jammu's Muslim pockets, thereby creating new alignments. So far, the political divide in the state generally has been regional rather than religious based. This is not to argue that communal factor did not operate at all. On the contrary, the communal identity was invoked for electoral purposes by almost all the political parties, including the National Conference. However, the impact of such mobilisation remained limited and did not succeed in carving a communal constituency. During the Amarnath agitation, the aggressive Hindu religious mobilisation and backlash against Muslims, in certain cases, resulted in communal wedge. As a result, Kashmiri leaders both from the separatist camp as well as from the mainstream parties sought to create a political constituency among Jammu Muslims. The unprecedented victory of PDP in two Muslim dominated constituencies signalled the success in this direction.

The impact of Amarnath agitation as reflected in the Assembly elections raised major questions related to the future of the state. If the divisive forces were to dominate the politics of the state, it would threaten the integrity of the State. The state, despite its diversity and political divergence, had continued to remain integrated due to the endurance of the centrist forces. The centrist forces actually affirmed the plural nature of society. With the radical forces occupying the central space, the very plurality of the state has been endangered. 


\section{The 2009 Parliamentary elections}

The 2009 Parliamentary elections took place barely few months after the Assembly elections, thus dealing with the concerns and anxieties raised due to the outcome of the Assembly elections. This election, being relatively more distanced from the Amarnath agitation, provided important clues about the depth of the impact of the divisive tendencies sharpened during the agitation. It also provided interesting insights into the relationship between the mainstream and separatist politics in Kashmir.

\section{The context of separatist politics}

Defiance of the boycott call and enthusiastic participation of people in the Assembly elections resulted in a sense of demoralisation in the separatist camp. The growing space of the mainstream politics did not induce a simultaneous shrinking of the separatist space ${ }^{17}$, but it did lead to a change in orientation within the separatist camp. The impact of this shift could be seen during the Parliamentary elections, when Sajjad Gani Lone, a prominent separatist took the decision to contest the 2009 Parliamentary election from Baramula constituency of North Kashmir.

Sajjad Lone led one of the leading separatist organisation, the People's Conference (PC) which was a part of the All Party Hurriyat Conference (APHC) right from the time of its inception in 1993. As an amalgam of the separatist and militant organisations active in Kashmir, APHC represented the popular separatist sentiment in Kashmir. ${ }^{18}$ A G Lone, father of Sajjad Lone and the founder of the People's Conference was one of the most prominent leaders of the APHC.

Though many other separatists had earlier joined the electoral fray, the Sajjad Lone's decision to contest Parliamentary election had an altogether different impact. Being a high profile separatist, at par with the top separatist leaders like Mirwaiz Omar Farooq, Ali Shah Geelani and Yasin Malik, one could see in his decision to contest election a crack within the separatist politics. The crack was very small, not seeming to affect the separatists overtly but in reality had had a great psychological effect on them. More so since his decision to contest election came in the wake of the massive participation of Kashmiris in the Assembly elections.

50 Separatists had been very aggressive in their boycott call during the 2009 Parliamentary elections. Though the call was initially given by Syed Ali Shah Geelani, the hardliner leader of the Hurriyat $(\mathrm{G})$, soon the other faction of Hurriyat led by Mirwaiz Omer Farooq and other organisations joined the boycott campaign.

51 The voter enthusiasm was quite low this time. Against 51\% turnout during the Assembly election, only $31.24 \%$ votes were registered during this election. It was partially the impact of the aggressive campaigning by the separatists that the voter participation during the Parliamentary elections was relatively lower.

Table 4. Comparative voter turnout in Kashmir region - 2008 Assembly elections and 2009 Parliamentary elections

Voter turnout (\%) 


\begin{tabular}{|l|l|l|}
\hline & $\begin{array}{l}2008 \\
\text { Assembly elections }\end{array}$ & $\begin{array}{l}2009 \\
\text { Parliamentary elections }\end{array}$ \\
\hline J\&K & 60.92 & 39.66 \\
\hline Kashmir & 51.64 & 31.24 \\
\hline Jammu & 70.90 & 47.19 \\
\hline Ladakh & 68.65 & 71.85 \\
\hline
\end{tabular}

52 It is important to analyse as to why the same voters who showed enthusiasm in 2008 shied away from the same process in the Parliamentary election? Why did the separatists' call for boycott succeeded this time? A number of reasons can be attributed to this. Firstly, the kind of proximity and involvement that the voters felt with the Assembly elections was missing during the Lok Sabha elections. Governance is becoming important to people and therefore they are keen to have a party in power with which they identify. ${ }^{19}$ This is why they defied the call for boycott during the Assembly elections. During the Parliamentary election, the boycott call could become effective because people did not have similar stakes. Not voting during these elections was a message that many Kashmiris would have wanted to give to the Central government-that their participation in the Assembly elections should not be construed as their complete rejection of the separatist politics. In the context of the complexity of relationship between the separatist and mainstream politics in Kashmir, it needs to be reiterated that the expansion of the mainstream politics does not necessarily take place at the cost of the separatist political space. Separatist sentiments continue to dominate the popular political responses despite their positive response to the mainstream politics. It is the assertion of the separatist sentiments that was reflected in the boycott politics. Lest the participation of the people during the Assembly elections should be seen as an endorsement of Indian position on Kashmir, the people sought to use the strategy of boycott politics to assert their continued contestation of this position.

However, despite the lower voter turnout in the Parliamentary elections as compared to their turnout in the Assembly elections, participation of Kashmiris showed an improvement as compared to their participation in the earlier Parliamentary election. In all the three constituencies of the Valley, the voter turnout this time was higher than in 2004 Parliamentary elections.

Table 5. Comparative voter turnout in all the constituencies of the State -2004 and 2009 Parliamentary elections

\begin{tabular}{|l|l|l|}
\hline & \multicolumn{2}{|l|}{ Voter turnout (in \%) } \\
\hline & $\begin{array}{l}\mathbf{2 0 0 4} \\
\text { Parliamentary elections }\end{array}$ & $\begin{array}{l}\mathbf{2 0 0 9} \\
\text { Parliamentary elections }\end{array}$ \\
\hline Baramulla & 35.65 & 41.84 \\
\hline Srinagar & 18.57 & 25.55 \\
\hline
\end{tabular}




\begin{tabular}{|l|l|l|}
\hline Anantnag & 15.04 & 27.09 \\
\hline Ladakh & 73.52 & 71.86 \\
\hline Udhampur & 45.09 & 44.88 \\
\hline Jammu & 44.49 & 49.03 \\
\hline
\end{tabular}

On the basis of this data one can infer that although separatist politics has affected the responses of people in the Valley to the extent that many of them chose to remain away from the Parliamentary elections, their response cannot be construed to mean a total rejection of the electoral process. As the electoral data of 2004 elections shows, the stake of people in the Parliamentary elections is not as high as in the Assembly elections. Even when the faith of the people in the electoral politics had increased due to a very credible electoral process during the 2002 Assembly elections, their participation in the 2004 Parliamentary elections remained low. The overall expansion of the electoral space that was taking place in the post-2002 period was not reflected during the Parliamentary elections, even when at the ground level one could see the difference. The political environment was energised by intense political competition between the two regional parties-the NC and the PDP which were not only mobilising people and holding huge rallies but were also engaging people at the discursive level through their different versions/models of peace process. One could see the intensity of this politics throughout the year 2007 and 2008 (till the Amarnath agitation took place). The massive participation of the people during the 2008 Assembly elections clearly established as to how this politics had been legitimised.

However, separatist politics remains the reality of Kashmir and despite the extension of mainstream politics, and will remain intact mainly due to the fact that there is a longstanding alienation among people which needs to be addressed. Much of this alienation is the result of the disjuncture between the power politics and the local responses. Politics generally operated at a level where people were not involved-even in the discursive sense. Not a single local debate took place about the kind of political arrangements the state required, or the major political changes implemented since 1953. The competitive nature of power politics has changed this context. Rather than depending upon the Centre for its legitimaty, the power politics now depends on popular responses and is rooted in the local milieu.

\section{Implications of the Amarnath agitation}

56 To what extent had the Amarnath agitation changed the nature and course of politics of the state? Was the political response reflected during the Assembly election symptomatic of the change in the nature of politics? Or was it merely a passing phenomenon? An analysis of the 2009 Parliamentarly election is important for reflecting upon these questions.

57 Though not much time had passed between the Assembly and the Parliamentary elections, the ground level situation in the state had witnessed substantial changes which had implications on the Parliamentary elections. 
lost its impact soon after the situation became normal, both in Jammu as well as in lost its impact soon after the situation became normal, both in Jammu as well as in Kashmir. In Jammu, however, there was a rethinking about the agitation and the effect that it had on the region as a whole. Apart from the huge economic loss that people suffered due to the agitation, there was a feeling that Jammu did not gain much from the agitation. The massive regional sentiment that was generated during the agitation was not translated into any positive achievement for the region. On the contrary there was lot of negative baggage of the agitation. The traders, who form the economic backbone of the region, had to face the wrath of their Kashmiri counterparts who responded to the 'economic blockade' of the Valley during the agitation, by taking a decision to bypass Jammu in trade activities. However, it was the communal aftertaste of the agitation that made the people uneasy. ${ }^{20}$ The aggressive anti-Muslim posture of the fringe organisations activated during the agitation, the sporadic attacks on some Muslims and the outburst of communal violence in two towns of the region did not go very well with the local sensibilities.

\section{The impact of rethinking the Parliamentary elections}

61 Being partners in power, the NC and the Congress had reached a pre-electoral arrangement for contesting the 2009 Parliamentary elections. Due to its stronghold in the Valley, the NC contested the three seats of the Valley, while the Congress having its base in Jammu, fielded its candidates in both constituencies of the region. The third seat of Ladakh was also contested by the Congress. As a consequence of this alliance, the contest was regionally localised. There was a direct fight between the NC and PDP in the Valley and between the Congress and BJP in Jammu region.

The strategy of the coalition partners to contest in alliance helped them to gain both in the Valley as well as in Jammu region. The NC-Congress combine was able to sweep the Parliamentary elections winning five of the six seats. The sixth seat was also won by the rebel candidate of $\mathrm{NC}^{21}$ In two of the three constituencies of the Valley, the margin of votes attained by the winning NC candidate over their PDP rivals was quite high. It was only in Anantnag constituency that there was a close contest between the two parties. In the case of Jammu region also, the Congress was able to win the Jammu seat with a very

South Asia Multidisciplinary Academic Journal, 3 | 2009 
solid majority and it was only in Udhampur constituency that there was a neck-to-neck fight between the Congress and the BJP candidates.

Table 6. Performance of NC, Congress, PDP and BJP - 2009 Parliamentary elections

\begin{tabular}{|l|l|l|l|l|}
\hline & Winner & Votes (in \%) & Runner Up & Votes (in \%) \\
\hline Baramulla & NC & 46.01 & PDP & 31.32 \\
\hline Srinagar & NC & 51.99 & PDP & 41.30 \\
\hline Anantnag & NC & 46.53 & PDP & 44.89 \\
\hline Ladakh & IND & 29.84 & INC & 26.48 \\
\hline Udhampur & INC & 37.90 & BJP & 35.71 \\
\hline Jammu & INC & 45.33 & BJP & 30.94 \\
\hline
\end{tabular}

\section{The Kashmir region}

In Kashmir Valley, the NC not only registered its victory in all the three seats of the region, but also improved its share of votes compared to earlier election. With $38.42 \%$ votes cast in its favour during the 2004 Parliamentary election, it obtained $49.79 \%$ votes during the 2009 Parliamentary elections. This poll percentage was quite high as compared to the $38.12 \%$ votes polled by the PDP (slightly lower than its voter turnout of $39.29 \%$ in 2004). While the improvement of its share of votes was reflected in each individual constituency, however, it was in Anantnag constituency that the NC actually doubled its share of votes as compared to $2004^{22}$ (from $23.63 \%$ in 2004 to $46.53 \%$ in 2009 ).

Table 7. Votes polled (\%) by NC and PDP in Kashmir Region - 2009 Parliamentary elections

\begin{tabular}{|l|l|l|}
\hline & NC (in \%) & PDP (in \%) \\
\hline Kashmir region & 49.79 & 38.12 \\
\hline Baramulla & 46.01 & 31.32 \\
\hline Srinagar & 51.99 & 41.30 \\
\hline Anantnag & 46.53 & 44.89 \\
\hline
\end{tabular}

The loss of Anantnag seat was a huge setback for the PDP. Interestingly, Anantnag is the stronghold of the PDP. The PDP has been dominating both the Parliamentary as well as Assembly constituencies. In 2004 Parliamentary election, the seat was won by Mehbooba Mufti with 49.55\% votes. And during the 2008 Assembly elections, the party had swept the four districts falling in this constituency, bagging 12 of the total 16 seats. What reflected the great decline of the party was its performance in two Assembly segments of Anantnag 
and Wachi from where Muft Syed, the patron of the party and Mehbooba Mufti, the party president, had registered their victory with massive mandate during the Assembly election. During the Parliamentary elections, the vote share of PDP in both these segments had fallen drastically.

Table 8. Comparative performance of NC and PDP - 2004 and 2009 Parliamentary elections

\begin{tabular}{|c|c|c|c|}
\hline & & \multicolumn{2}{|c|}{ Votes polled (in \% } \\
\hline & & NC & PDP \\
\hline \multirow{2}{*}{ Kashmir region } & 2004 & 38.42 & 39.29 \\
\hline & 2009 & 47.79 & 38.17 \\
\hline \multirow{2}{*}{ Baramula constituency } & 2004 & 38.13 & 35.18 \\
\hline & 2009 & 46.01 & 31.32 \\
\hline \multirow{2}{*}{ Srinagar constituency } & 2004 & 50.3 & 38.46 \\
\hline & 2009 & 51.99 & 41.30 \\
\hline \multirow{2}{*}{ Anantnag constituency } & 2004 & 23.63 & 49.55 \\
\hline & 2009 & 46.53 & 44.89 \\
\hline
\end{tabular}

The loss of the PDP in the Parliamentary elections reflected a change of mood at the ground level since the Assembly elections. The lower level of participation during the election also affected the election outcome. The PDP's was incapable to mobilise as it had during the Assembly election, thus revealing its complacency during the Parliamentary elections. Buoyant by its performance during the Assembly elections, the party had taken its victory for granted during the Parliamentary election. And may be due to this sense of complacency or may be to show some kind of proximity with the separatist politics, neither Mehbooba nor Mufti Syed cast their own votes.

The PDP's failure to retain its own ground in the Valley could be seen as a rejection of the 'soft-separatism' of the party. In order to ground its politics in the local sensibilities, the PDP borrows heavily from the separatist agenda and often seeks to use emotive slogans to strengthen its constituency. Even when it was a part of government, it continued to use the populist rhetoric in order to claim its proximity with the separatist sentiments of people. It was in the same vein that the party had joined the Amarnath agitation and had sought to raise the emotive pitch of Kashmir's politics. Though the party could gain during the Assembly elections which was conducted in the heat of the sentiments raised during the Amarnath agitation, it could not take advantage during the Parliamentary elections. As the situation was normalised, the party lost support at the ground level.

With the rejection of PDP during the Parliamentary elections, the Kashmir region also seems to have rejected the polarised regional politics of the state. The PDP's role in sharpening the regional divide equals to that of the BJP. Both the parties gain mutually by 
stretching the regional politics on opposite side. While BJP sharpens the pro-Jammu sentiments, the PDP arouses pro-Kashmir sentiments. The mutual exclusivity of both the sentiments aggravates the regional divide. The fact that the communal elements automatically creeps in this kind of aggressive regional mobilisation, makes this politics quite dangerous.

Since Kashmir remains the most important constituency, the NC also indulges in the proKashmir politics. However, what distinguishes the PDP's politics from the NC's is that the former invokes 'region' as well as 'religion' in a more aggressive manner. NC's Kashmircentric politics is more oriented towards the Centre, making demands upon it on behalf of the State (therefore, its emphasis on State Autonomy). The PDP's politics is more inward looking and therefore focuses on Kashmir region defined in antagonistic terms vis-à-vis Jammu region. In the definition of regional identity, the religious element of Kashmiri identity is also invoked.

\section{The Jammu region}

69 In Jammu region, the BJP was expecting to register its victory in both the seats. During the 2008 Assembly elections it could return 11 Assembly seats. The performance of the BJP in this election had raised the hopes of this party for the Parliamentary elections. However it lost both the seats to Congress. As against the $42.20 \%$ votes polled by the Congress, it could poll only $32.94 \%$ votes. $^{23}$

Table 9: Votes polled by BJP and Congress in Jammu region - 2009 Parliamentary elections (\%)

\begin{tabular}{|l|l|l|}
\hline & BJP & Congress \\
\hline Jammu region & 32.94 & 42.20 \\
\hline Udhampur constituency & 35.71 & 37.90 \\
\hline Jammu constituency & 30.94 & 45.33 \\
\hline
\end{tabular}

Though both the seats of Jammu have remained the traditional strongholds of the Congress, the BJP could gain from the communal polarization during the peak of militancy and win both the seats during the 1998 and 1999 Parliamentary elections. However during the 2004 elections it lost both the seats. Its expectations in the postAmarnath agitation were quite high and it had expected its victory this time as well given the intensified mobilization by this party in the Hindu dominated areas of the region and the consequent polarization between the communities that was reflected during the period of agitation. ${ }^{24}$

Table 10. Comparative performance of BJP and INC in Jammu region - 2004 and 2009 Parliamentary elections

\begin{tabular}{|l|l|l|}
\hline & \multicolumn{2}{|l|}{$\begin{array}{l}\text { Votes polled (in \% } \\
\text { ) }\end{array}$} \\
\hline & 2004 & 2009 \\
\hline
\end{tabular}




\begin{tabular}{|l|l|l|}
\hline BJP & 34.72 & 32.94 \\
\hline INC & 39.22 & 42.20 \\
\hline
\end{tabular}

Table 11. Jammu constituency over the years: Results of the Parliamentary elections from 1989 to $\underline{2009}$

\begin{tabular}{|l|l|l|}
\hline & \multicolumn{2}{l|}{$\begin{array}{l}\text { Votes polled (in \% } \\
\end{array}$} \\
\hline & BJP & Congress \\
\hline $\mathbf{1 9 8 9}$ & 6.16 & 41.82 \\
\hline $\mathbf{1 9 9 6}$ & 26.00 & 34.24 \\
\hline $\mathbf{1 9 9 8}$ & 43.26 & 18.11 \\
\hline $\mathbf{1 9 9 9}$ & 43.46 & 41.82 \\
\hline $\mathbf{2 0 0 4}$ & 36.81 & 38.94 \\
\hline $\mathbf{2 0 0 9}$ & 30.94 & 31.85 \\
\hline
\end{tabular}

Table 12. Udhampur constituency over the years: Results of the Parliamentary elections from 1989 to 2009

\begin{tabular}{|l|l|l|}
\hline \multicolumn{2}{|l|}{$\begin{array}{l}\text { Votes polled (in \% } \\
\end{array}$} & \multicolumn{2}{l|}{ BJP } & Congress \\
\hline $\mathbf{1 9 8 9}$ & 12.63 & 40.66 \\
\hline $\mathbf{1 9 9 6}$ & 37.58 & 21.74 \\
\hline $\mathbf{1 9 9 8}$ & 48.67 & 7.13 \\
\hline $\mathbf{1 9 9 9}$ & 49.01 & 19.09 \\
\hline $\mathbf{2 0 0 4}$ & 31.85 & 39.61 \\
\hline $\mathbf{2 0 0 9}$ & 30.94 & 45.33 \\
\hline
\end{tabular}

71 One definite message that is given by the voters during the Parliamentary elections in Jammu region is that politics here cannot be controlled by the rightist forces for a long time. In very certain terms people have shown their antipathy towards the forces that aim at mobilizing them on religious basis, polarizing them on communal grounds and generating tensions within the region. People might have been temporarily swayed by 
the emotions raised during the Amarnath agitation, but that is not the normal political mood of the region. In defeating Leela Karan Sharma from Jammu-Poonch Parliamentary constituency, the people have distanced themselves not only from the politics of Amarnath agitation but from the communal politics per se. The BJP, despite opposition from within the cadre, had taken the decision to give ticket to Leela Karan because as chairman of the Amarnath Sangharsh Samitie, he had become the most important face of the agitation ${ }^{25}$. Confident that the BJP could gain from the popularity of Leela Karan during the agitation, the party leadership had gone ahead with the Leela Karan's candidature. Leela Karan, however, lost the election with a big margin.

The natural direction of politics of Jammu is quite secular and is manifested in secular manner in a variety of ways. The plurality of Jammu as well as its multi-layered social and political dynamics compels the regional politics to take a secular shape. However, in the absence of a secular regional politics that takes into consideration not only the sensitivities of the Hindu-heartland of Jammu region but also carries within itself the political concerns of the backward sub-regions at the periphery, the politics has all the possibilities of becoming communally divisive. About Amarnath agitation, one can safely say that, though it was manifested in religious terms, the major reason for the mass mobilization was regional rather than religious. This leads us to argue that communal elements which generally remain at the margins of Jammu's politics, seek to appropriate the regional discontent at any time they can and change the very direction of popular responses.

\section{Conclusion}

This paper has sought to analyse the intricacies of the electoral politics of the state by locating it in the prevailing separatist context in the Valley of Kashmir on the one hand and increasing political divergence on regional basis on the other. The paper has sought to highlight the reality of separatist politics in Kashmir, despite the fact that there is increasing space for the mainstream politics. The electoral politics which had become totally irrelevant in the Valley during the late eighties, in the wake of militancy and political upsurge, has again acquired legitimacy not only due to a shift in the nature of the resistance politics but also due to the changed context of mainstream politics. With the emergence of PDP as another regional party of Kashmir, the hegemony of the National Conference has been fractured and the intensity of electoral competition has increased. Consequently, the possibilities of manipulation of the electoral politics by the ruling party in the centre have become quite remote and the distance between the electoral politics and the popular responses (that always used to characterise the Kashmir's electoral politics) has been significantly reduced.

The legitimacy of the electoral politics, however, has been attained within the overall context of separatism. Rather than challenging the separatist politics, the political parties have sought to recognise the reality of the conflict situation and limit the scope of their politics to issues of 'governance' only. The divide between the 'politics of governance' in which the political parties indulge and the 'politics of the ultimate resolution of conflict' which is seen as the domain of the separatist politics is generally recognised by the political parties, separatist leaders as well as by the common masses. 


\section{BIBLIOGRAPHY}

Abdullah, Farooq (1985) My Dismissal: As Told to Satti Sahni, New Delhi: Vikas.

Akbar, M. J. (1991) Kashmir: Behind the Vale, Delhi: Viking.

Bose, Sumantra (1997) The Challenge in Kashmir: Democracy, Self-Determination and a Just Peace, New Delhi: Sage.

Bose, Sumantra (2003) Kashmir: Roots of Conflicts, Paths to Peace, Delhi: Vistaar Publisher.

Chowdhary Rekha (2000) ‘Autonomy Demand: Kashmir at Crossroads', Economic and Political Weekly, 22 July.

Chowdhary Rekha \& Nagendra Rao (2003) 'Jammu and Kashmir: Political Alienation, Regional Divergence and Communal Polarisation', in Journal of Indian School of Political Economy, 15(1-2), January-June.

South Asia Multidisciplinary Academic Journal, 3 | 2009 
Chowdhary Rekha \& Nagendra Rao (2004) 'National Conference of Jammu and Kashmir: From Hegemonic to Competitive Politics', Economic and Political Weekly, 3-10 April.

Chowdhary Rekha (2008) 'Electioneering in Kashmir: Overlap between Separatist and Mainstream Political Space', Economic and Political Weekly, 12 July.

Ganguly, Sumit (1997) The Crisis in Kashmir: Portents of War, Hopes of Peace, Cambridge: Cambridge University Press.

Hewitt, Vernon (1995) Reclaiming the Past: The Search for Political and Cultural Unity in Contemporary Jammu and Kashmir, London: Portland.

Puri, Balraj (1966) Jammu: A Clue to Kashmir Tangle, Delhi: B. Puri.

Puri, Balraj (1983) Simmering Volcano: Jammu's Relation with Kashmir, Delhi: Sterling.

Puri, Balraj (1993) Towards Insurgency, New Delhi: Orient Longman.

Schofield, Victoria (2000) Kashmir in Conflict: India, Pakistan and the Unending War, London: I B Tauris.

\section{NOTES}

1. For a detailed understanding of the background and emergence of armed militancy and separatist politics of Kashmir, see M J Akbar (1991), Sumit Ganguly (1997), Victoria Schofield (2000), Sumantra Bose $(1997,2003)$, Vernon Hewitt (1995)

2. Along with MUF, the opposition to the NC-Congress combine was given by the People's Conference led by Abdul Gani Lone. While MUF could poll 31.8\% votes, the People's Conference could get $6.4 \%$ votes.

3. For instance, the NC candidate in Bijbihera won the election with a margin of 100 votes only. In Wachi the margin of victory of the winning candidate was of 122 votes and in Shopian it was of 336 votes. Moreover, there was a huge number of votes which were declared invalid. Thus $6.7 \%$ votes polled in Doru, 5.6\% in Chrar-e-Sharief, $4.9 \%$ in Homshilbug, $4.8 \%$ in Wachi and Sangrama each, $4.5 \%$ in Amirakadal and $4.2 \%$ votes in Handwara were rejected. In most of the constituencies of narrow victories, the number of invalid votes was quite high. In fact in the three above stated constituencies of Bijbihera, Wachi and Shopian with very narrow margins of victory, the number of invalid votes was much higher than the margin with which the winning candidates had been declared victorious. Thus 1177 votes were declared invalid in Bijbihera, 1806 in Wachi and 1122 in Shopian.

4. With common people openly identifying with separatist politics, the farcical nature of the electoral politics became very clear during the 1989 Parliamentary elections. Not only were there not many keen contestants ready to fight this election, but there were also not many voters ready to vote. For the two of three constituencies which went to poll (the third was returned uncontested), only $5 \%$ voters cast their votes.

5. It was exactly $29.64 \%$ voter turnout for the Valley of Kashmir. Interestingly in few districts like Kupwara, Budgam and Baramulla, the voter turnout was as high as $53.15 \%, 46 \%$ and $40.09 \%$ respectively. The voter turnout in Ananntnag and Pulwama was moderate-24.05\% and $23.68 \%$ respectively. It was in the Srinagar district that the lowest turnout-11.17\%.

6. That is the reason why the National Conference, which was ousted from power in 1984 due to the defections engineered by the Congress, not only risked its popularity by going in for an alliance with the same party, but also took the open position of remaining on the right side of the ruling party of the Centre in order to stay in power. Going against its own ideology, it even chose to side with the BJP-led NDA during the late nineties. 
7. Sheikh was arrested on the suspicion that he was not happy with the Accession of the State with India and was hobnobbing with the Americans around the idea of independence of Kashmir. However, as Mir Qasim has revealed in his book, he was also a victim of a local conspiracy led by his own cabinet colleagues led by Bakshi Ghulam Mohd.

8. The disjuncture between the National Conference and the popular responses was also reflected earlier, especially after the Party opted for entering into alliance with the Congress party. The support that the Muslim United Front enjoyed before the 1987 Assembly election was mainly due to the disillusionment with the politics that this party was pursuing.

9. The competitive nature of regional politics of Kashmir ultimately resulted in deeper changes in the power politics of the State. The fragmented verdict at the regional level and the failure of any party to obtain a majority of seats led to the formation of a coalition government. The important aspect of this post-2002 coalition politics is that is it representative of both regions. Fragmented verdict during the 2002 Assembly election led to the alliance between the PDP and the Congress and formation of their government along with few other smaller parties. The NC emerged as the largest party with presence in all the three regions of the state and chose to sit in opposition. This arrangement reflected greater democratisation of the politics of the state from a number of angles. Apart from the fact that the politics of Kashmir had become intensely competitive and rooted in local concerns, it had, for the first time, space for genuine opposition. The NC due to its numerical strength could operate as an effective opposition party and could put sufficient pressure on the ruling coalition. Meanwhile, there was a wider base for the government with one of the coalition partners having its support base in Kashmir region, the other in Jammu.

10. Shri Amarnath Shrine Board was formed by the government of J\&K in 2000 with the purpose of managing the pilgrimage to Amarnath shrine in South of Kashmir. During the peak of summer, the shrine attracts thousands of pilgrims from all over India.

11. General Sinha had earlier incensed many Kashmiris with a self-proclaimed agenda of changing the 'mindset' in Kashmir which he set about doing by redefining 'Kashmiri-yat' based essentially on its Hindu past. As chancellor of the University of Kashmir, he patronised the Centre for Kashmir Studies which was frequently used to propagate his views.

12. After the first phase of agitation which culminated with the revocation of the Government Order, the agitation acquired a form in which the two regions were placed in a completely antagonistic form. The revocation of the Order after the mass response in Kashmir was projected as anti-Hindu and anti-Jammu act of the state government and therefore led to a prolonged agitation in Jammu which lasted for more than two months. To quell the sharpened regional response in Jammu, the State government took the decision to restore 800 canal of land in Baltal to Shri Amarnath Shrin Board. This government decision led to a fresh phase of agitation in Kashmir during which sharp regional sentiments were expressed. Specifically, there were reactions against the 'economic blockade' of Kashmir during the Jammu agitation. So strong was the anti-Jammu response in Kashmir at that time that the traders took a decision to severe their links with their Jammu counterparts.

13. Since 2002, when the era of coalition politics started, Jammu started having a substantial share in power politics. That is the reason why the voices raising the demand for a separate Jammu state were not raised and the forces of Right were quite marginalised (this was reflected in just one seat in favour of BJP and one for Jammu State Morcha). However during the Amarnath agitation, the forces of Right were able to mobilise the people from urban centres of Jammu by combining religious sentiment with regional factor.

14. Though much of the electoral discourse in Kashmir revolves around the 'bigger issues' like the ideas of 'self-government', 'autonomy', there are also issues which confront the people on routine basis. The idea of de-militarisation of PDP, for instance, is very much located in the problems faced by people due to the continued presence of security forces. The 'healing touch' 
policy advocated by PDP similarly involves the rehabilitation of people adversely affected by violence.

15. The communal polarisation of the electoral politics of the State is not unprecedented. The 1983 Assembly elections are known to be one of the most communally polarised elections of the State. In an intensely contested election between the National Conference and Congress, the Congress was able to mobilise the Hindu voters of Jammu and register its massive victory in this region.

16. With Congress-PDP being the major partners of the coalition government, it represented a balance of forces between Jammu and Kashmir. Congress was having its strong base in Jammu and the PDP in Kashmir. Besides a very effective representation of Jammu based leaders in the Ministry, there was a system of rotation for the position of CM and Deputy CM between the two parties and regions. For the first three years of the coalition, the position of Chief Minister was held by Kashmir based PDP leader Mufti Mohd Sayeed (with Mangat Ram Sharma of Congress, a leader of Jammu holding the position of Deputy $\mathrm{CM}$ ) and after that the position of $\mathrm{CM}$ was held by Ghulam Nabi Azad, a Jammu-based Congress leader with Muzzafar Hussain Beg of PDP holding the position of Deputy CM. Due to the changed context of power structure, the scope of politics based on regional discontent was somewhat restricted.

17. It cannot be argued that the positive response of the Kashmiris towards the electoral process has amounted to the decline in their separatist sentiments. On the contrary, the assertion of the separatist sentiments, especially since the Amarnath agitation, has become more intense. One can see the intensity of such sentiments through the mass demonstrations against cases of Human Rights violations. Ever since 2007, such demonstrations have been frequently organised all over the Valley. A glimpse of the deep-rooted separatist sentiment is also given by the massive funeral processions of the militants killed by the security forces.

18. Though the present phase of Kashmir separatist politics was initiated in 1989, it was only in 1993 that the APHC was formed to give a political face to the separatist sentiment. This sentiment was represented till that time, by the armed militancy on the one hand and the spontaneous popular upsurge on the other. Throughout the period of 1990, there were massive demonstrations in Kashmir Valley. Thousands of people would march on the streets raising the slogan of Azadi. The repressive measures adopted by the state soon restrained the public expression of the mass response, the intensity of the armed militancy, however continued. The beginning of the decade of 1990s saw a mushroom growth of militant organizations. Apart from Jammu Kashmir Liberation Front (JKLF), the initiator of armed militancy in Kashmir, the Hizbul Mujahideen, had emerged as the major militant organization having a local support base. The Hizb, supported by Pakistan, launched soon after its emergence a major offensive on JKLF and succeeded in eliminating its cadres to a large extent. It was in this context of the mutual rivalry that a need was felt to organise all the militant and separatist groups under the banner of a single umbrella organization. The All Party Hurriyat Conference was therefore organised in 1993. 19. The high expectations that people have from the local politicians were demonstrated in 2007 when various agitations were launched around the issue of opening of colleges and restructuring of the districts and Tehsils.

20. Interestingly, there has been a strong refutation of the communal charge on the part of the vocal middle class, media, traders and the politicians of Jammu. Soon after the agitation, the regional dimensions of the agitation were highlighted and the religious sentiments expressed during the agitation were underplayed.

21. Though the seat of was officially contested by the Congress candidate, the NC cadre of Ladakh rather than supporting him, worked for the victory of the NC rebel candidate who was able to wrest the seat defeating the official candidate of the alliance partners.

22. In Baramulla constituency, the NC candidate Sharif ud din Shariq won the election by polling 203022 votes as against 138208 votes of PDP candidate Mohammad Dilawar Mir. Sajad Gani Lone 
of People's Conference polled 65403 votes. Please elaborate on the defeat of S.G. Lone. In Srinagar constituency, NC candidate Farooq Abdullah won the election by polling 147075 votes as against 116793 of Moulvi Iftikhar Ansari of PDP. In Anantnag constituency, Mirza Mehboob Beg won the election by polling 148317 votes as against 143093 votes polled by PDP candidate, Peer Mohd. Hussain.

23. In Udhampur constituency, the Congress candidate, Ch. Lal Singh won the election by polling 2318153 won the seat by defeating BJP candidate Dr. Nirmal Singh who polled 218459 votes. In Jammu constituency, the Congress candidate, Madan Lal Sharma won the election by polling 382305 votes as against 260932 votes polled by his nearest rival, Leela Karan Sharma of BJP.

24. However, the effect of the mobilization by the BJP does not seem to be lasting. Though it could get a large number of votes from Hindus (exceeding its hold from 11 Assembly segments to 13), it failed to get the advantage of winning the seats as it had in 1998 and 1999. It could not get all the Hindu votes of the region. The Congress could get a substantial number of Hindu votes. (The NC-Congress combine also gained in the region-with lead in 21 Assembly segments as compared to victory in 19 seats during 2008 Assembly elections).

25. The opposition to Leelakaran's candidature came from within the party on the ground that he was seen as an outsider who had not been associated with the politics of BJP in any form.

\section{ABSTRACTS}

The paper analyses the 2009 Parliamentary elections in Jammu and Kashmir in the context of the conflict situation of the last two decades. The separatist sentiment, the paper argues, remains ascendant, even though mainstream politics (that had become totally irrelevant during the initial years of militancy and political upsurge) has been gradually gaining space. Rather than challenging separatist politics, mainstream politics is seeking to legitimise itself by acknowledging its own limitations and confining itself to the politics of 'governance' while leaving for separatist politics the issue of the 'ultimate resolution of conflict'. However, in this process of legitimisation, mainstream politics has taken up many issues from the agenda of separatist politics. Consequently, despite the distinction between the two kinds of politics, there exists an overlap between them. The paper also focuses on the political divergence and the assertion of regional/religious identity politics. The Amarnath agitation, which took place a few months before the Parliamentary elections, became the basis of massive political mobilisation and reaffirmation of the popular separatist sentiment in Kashmir and religious cum regional identity politics in Jammu. As such, it forms an important reference point for the analysis. The paper also focuses on the 2008 Assembly election, which immediately preceded the Parliamentary elections.

\section{INDEX}

Keywords: conflict, democracy, elections, India, Jammu, Kashmir, political science 


\section{AUTHOR}

\section{REKHA CHOWDHARY}

University of Jammu, Department of Political Science 